\title{
Swag-Bellied Hollanders and Dead-Drunk Almaines: Reputation and Pseudo-Translation in Early Modern England
}

\author{
DEMMY VeRBEKe
}

Catholic University of Leuven, Belgium

In early modern England, alcohol abuse was criticized in numerous publications appearing in diverse genres. Several of these consider it to be a recent problem and blame the imitation of Flemish, Dutch or German drinking culture. This article traces the reputation of the Low Countries and Germany as heavy-drinking nations. It furthermore illustrates the desire of English authors and publishers to exploit this stereotype. Telling examples are Wine, Beere and Ale (1629) and Drink and Welcome (1637): both works were advertised as translations from either 'Low' or 'High Dutch', despite the fact that they are original English compositions. An analysis of these pseudo-translations shows that the forgery was not very convincing, but nonetheless added an element of humour or authority to the text, and thus highlights how they act as purveyors of cultural stereotypes about the inhabitants of the Low Countries and Germany.

KEYWORDS drinking culture, alcohol abuse, England, Low Countries, Germany

In I629, John Grove commissioned the London printer Augustine Mathewes to publish Wine, Beere, and Ale, Together by the Eares, a play which takes the form of a humorous dialogue between the three beverages mentioned in the title; their companions Sugar, Nutmeg, and Toast; and Water. ${ }^{\mathrm{I}}$ The alcoholic drinks contend for the title of 'Prince of liquors', but are in the end reconciled by Water who assigns each of them to a different level of society: wine is for the court, beer is for the city, and ale is for the countryside. The play concludes with a song repeating the outcome of the discussion:

Wine: I generous Wine, am for the Court.

Beere: The Citie calls for Beere. 
Ale: But Ale, bonny Ale, like a Lord of the Soyle, In the Countrey shall domineere.

Chorus: Then let us be merry, wash sorrow away, Wine, Beere, and Ale shall be drunke today. ${ }^{2}$

The play must have been quite successful, since Grove commissioned an expanded edition the following year, ${ }^{3}$ and again almost thirty years later, in $1658 .{ }^{4}$ In 1637 , another text appeared in London discussing similar issues and entitled Drinke and welcome: or the famous historie of the most part of Drinks. ${ }^{5}$ This text is divided into two parts. The first, in prose, offers a description and history of several alcoholic drinks, including cider, perry, mead, ale, beer and sack. The paragraph about ale is so extensive that this part in fact acts as a praise of it rather than a serious survey - as was already stated on the title page announcing that the work offers 'an especiall declaration of the potency, vertue, and operation of our English Ale'. The second part, in verse, discusses water in all its forms, and again incorporates a discussion of ale and beer, and why they are superior to wine.

Both these publications are advertised on their title pages as translations: Wine, Beere, and Ale as a translation from Dutch; Drinke and welcome as a translation from 'High Dutch' (meaning German). It quickly becomes obvious, though, that the Dutch or German originals cannot be traced because they simply never existed. James Hanford has argued that the play Wine, Beere, and Ale was written some time between I624 and I626 for performance at the University of Cambridge, and only afterwards prepared for publication. ${ }^{6}$ The reader is kept in the dark about the author of the dialogue, since the text is presented as a translation by a certain Mercurius Brittanicus (a British Mercury, i.e., the messenger of the gods) of an original written by a certain Gallobelgicus (an inhabitant of the Low Countries). Both are clearly humorous adaptations of pseudonyms used by the publishers of contemporary newsbooks. ${ }^{7}$ The second work, Drinke and welcome, is said to be 'Compiled first in the high Dutch tongue, by the painefull and industrious Huldricke Van Speagle, a Grammaticall Brewer of Lubeck, and now most Learnedly enlarged, amplified, and Translated into English Prose and Verse. By Iohn Taylor'. Huldrick Van Speagle is a fiction and it is in fact John Taylor, claiming to be the translator, who is the real author. ${ }^{8}$ Taylor seems to have been an expert on the matter of alcohol: besides this little book, he also wrote two consumer's guides to taverns and inns in London and the home counties, ran a London alehouse at the end of his life, and was at least twice arrested for being drunk and disorderly. ${ }^{9}$

These seventeenth-century publications about drunkenness, in other words, are pseudo-translations: they pretend to be English renditions of a source text in another language, whereas, in fact, they are original English compositions. But why are these particular texts marketed as translations? And why are they marketed as translations from either Dutch or German, but we do not come across similar texts on the same topic pretending to be translations from French, Spanish, Italian, or any other language? In order to answer these questions, one needs to look at the broader context and try to establish, first, why these texts about alcoholic drinks were produced at all; and, second, what the connection was between the debate on alcohol and the way Dutch and German drinking culture was perceived in England. 
As in the rest of early modern Europe, alcohol was omnipresent in sixteenth- and seventeenth-century England: it was a component of most people's daily diet, every special occasion or rite of passage was marked by a drink, and alcohol served as a fundamental part of medicine. ${ }^{\text {IO }}$ Alcohol abuse was therefore never far behind, although it seems that it was not before the last quarter of the sixteenth century that it was more generally acknowledged as a real problem. ${ }^{\text {II }}$ This is exemplified in George Gascoigne's Delicate Diet for daintiemouthde Droonkardes (I576) in which he proclaims that drunkenness is a 'beastlie vyce' and a 'monstruous plant', which only 'lately crepte into the pleasaunt Orchyardes of Englande'. ${ }^{\text {I2 }}$ Similarly, Thomas Thompson defines drunkenness in I6r2 as a 'diuelish deluge', which is 'now swelling ouer our good countrey to the hurt of the soyle, and the hindrance of Gods husbandry', ${ }^{13}$ and Robert Harris argued in I6I9 that the abuse of alcohol, perceived abroad, should be met at the frontiers of England, lest it would infest the island too, although he admits that he is rather too late than too early with this warning. ${ }^{\text {I }}$

Several dozens more works criticising alcohol abuse were produced during this period. Most of these texts have a serious, moral intent of warning the public of the dangers of drinking; others have a more entertaining purpose. They appear in several genres: pamphlets (e.g. An Inuective ageinst Glotony and Dronkennes, 1545), poetry (for example William Hornby's The Scourge of Drunkennes, I6I8), ballads and other single sheet prints (such as The Drunkards Dyall: or, good Sir, Your Nose is durty, c. I6I8, and The Great Sins of Drunkeness and Gluttony set forth in the proper Colours, I656), sermons (e.g. Thomas Kingsmill's The Drunkards Warning. A Sermon Preached at Canterbury in the Cathedral Church of Christ, I63I), and treatises which can be hundreds of pages long, as in the case of Richard Young's The drunkard's character of $1638 .{ }^{15}$ This group of original English works was furthermore expanded with translations of similar works written in Latin or a continental vernacular, such as Filippo Beroaldo's Declamatio de tribus fratribus, the English translation of which was most probably based on a French intermediary; ${ }^{16}$ or the translation into English of the Discorsi della vita sobria of Luigi Cornaro, based on a previous translation into Latin. ${ }^{17}$ Another similar text is A lytyll treatyse ... called The .ix. Drunkardes - according to its colophon 'translated out of duche into englyshe'. ${ }^{18}$ Research has brought to light the fact that the source text was probably compiled and/or printed by the Antwerp printer-publisher Jan van Doesborch, who was in London in 1523 when the English version was produced. ${ }^{19}$ The original is not extant, but there seems no reason to doubt that this treatise is indeed a translation from Dutch, published shortly after the original, which was perhaps brought to London by the compiler/ printer himself.

As already said, English texts criticising alcohol abuse frequently treat it as a foreign disease, which has only lately infected England. Authors in particular indicate German, Dutch and Flemish binge-drinkers as the ones whose drinking habits should not be imitated. ${ }^{20}$ It is important to realise that these English authors, especially in the sixteenth century, do not, generally speaking, make a distinction between the different 'Germanic' types: their use, especially, of the terms 'German' and 'Dutch' can refer to all inhabitants of the north-western part of Europe who speak a Germanic 
language. It is only late in the century, with the wars of independence, that a distinction is more generally made between the Dutch-speaking inhabitants of the Southern Netherlands (the Flemings or Flemish), the inhabitants of the independent Northern Netherlands (the Dutch), and the people living east of them (the Germans). ${ }^{2 \mathrm{I}}$ In any case, whatever they were called, all three of these groups were seen as heavy drinkers who set a bad example for the English. Gascoigne, for instance, blames the Germans who - in his words - 'of auncient tyme haue beene the continuall Wardens of the Droonkards fraternitye and corporation', ${ }^{22}$ but adds that the English are not completely blameless:

We were woont (in tymes past) to contempne and condempne the Almaines and other of the low Countreyes, for theyr beastly drinking and quassing. But nowe a dayes (although we use it not dayly lyke them, for it seemes that they are naturally enclyned unto that uyce) yet, when we doo make banquets and merymentes; as wee terme them, we surpasse them very farre: and small difference is founde betwixt us and them. ${ }^{23}$

Thomas Nash blames the interaction with the Low Countries for the recent surge in immoderate drinking in England and states that both the Germans and the inhabitants of the Low Countries are continually drunk:

[...] superfluitie in drink: a sinne, that euer since we haue mixt our selues with the Low-countries, is counted honourable: but before we knew their lingring warres, was held in the highest degree of hatred that might be. [...] The Germaines and lowe Dutch, me thinkes should be continually kept moyst with the foggie ayre and stincking mystes that arise out of theyr fennie soyle: but as their Country is ouer-flowen with water, so are their heads alwayes ouer-flowen with wine, and in their bellyes they haue standing quag-myres and bogs of English beere. ${ }^{24}$

The same argument, namely that it was at the time of Queen Elizabeth, when scores of English soldiers went to the Netherlands to fight in the war against Spain, that the English caught the disease of drinking and transported it back to their homeland, is repeated over and over again in the following decades. We find it for example in Henry Peacham's The compleat gentleman (I622) ${ }^{25}$ and Matthew Scrivener's Treatise against drunkennesse (I685). ${ }^{26}$

The connection between Germany and heavy drinking had already been made in earlier times. Tacitus states in his Germania $(22,2)$ that it was perfectly acceptable to pass an entire day and night drinking: 'diem noctemque continuare potando, nulli probrum'. This statement is repeated over and over again by early modern ethnographers. ${ }^{27}$ Thus, Joannes Boemus, in his Mores, leges, et ritus omnium gentium (I 520 ), says that the Germans 'would spend whole nights and dayes in drinking and carowsing, esteeming and accounting it a credit to be drunken'. ${ }^{28}$ John Barclay similarly indicates in his Icon animorum of I6I4 that the German nation 'is infected with a wonderfull loue of drinking, which now is a confessed vice, and therefore the more freely vsed'. ${ }^{29}$ He makes a similar case for the excessive habits of the inhabitants of the Low Countries, regardless of whether they live in the Southern or Northern Netherlands, who even give beer to their babies: 
Candida quidem, sed veluti coeli vitio depressa ingenia, quae etiam grauius bibendi intemperie stipant. [...] Quippe adhuc ab vbere pendentibus, quo paulatim lactis desiderium minuant, lagunculas ad similitudinem vberis effictas, et hordeaceo potu plenas, tradunt in manu.

Their wits are candid, but made grosser as it were by the fault of the climate, which yet they doe more depresse by the distemper of drinking [...] For they giue to their infants to abate their desire of milke, whilst yet they hang at their mothers breasts, bottles full of beere, made after the fashion of a dugge. ${ }^{30}$

Travel narratives and other contemporary sources seem to validate the reputation of Germany and the Low Countries as heavy-drinking nations. The statement that Dutch and Flemish children are literally brought up on alcohol is repeated in several English and Spanish accounts, as well as the argument that the cold and wet climate forces them to partake in alcohol generously in order to maintain their strength. ${ }^{3 \mathrm{I}}$ This apparently also included the academic community. Roger Ascham relates how he wanted to visit Petrus Nannius, the professor of Latin language and literature at the University of Louvain who had written a satirical dream-story criticising excessive behaviour amongst his students. ${ }^{32}$ However, he found him 'either drunken at home, or drinking abroad'. ${ }^{33}$ Joseph Scaliger, the Frenchman who became one of the most celebrated professors at the University of Leiden, likewise complained about the constant alcohol abuse of his Dutch colleagues, some of whom drank so much that they vomited at doctoral promotions, were too hungover to teach, and/or died prematurely of liver failure. ${ }^{34}$

The same national stereotype is present in English literary texts as early as the fourteenth century. Chaucer sets his Pardoner's Tale, which starts with a condemnation of the so-called tavern sins (gluttony, drunkenness, gambling and blasphemy), in Flanders, most probably because of the Flemings' reputation for heavy drinking. ${ }^{35}$ Moreover, the character of the drunk Fleming, Dutchman or German, who hardly speaks any English, misbehaves continually, and typically goes by the name 'Hans', appears frequently on the English scene. Examples are found in Ulpian Fulwell's Like Will to Like (I 567) and Thomas Dekker's The Shoemaker's Holiday (I 599). ${ }^{36}$ We also encounter the stereotype in Shakespeare's Othello, where Danes, Germans and Dutchmen are used as the standards of drinking abilities, surpassed by the English:

Iago: I learned it [i.e. a drinking song] in England, where indeed they are most potent in potting. Your Dane, your German, and your swag-bellied Hollander drink, ho! - are nothing to your English.

Cassio: Is your Englishman so exquisite in his drinking?

Iago: Why, he drinks you with facility your Dane dead drunk; he sweats not to overthrow your Almain; he gives your Hollander a vomit ere the next pottle can be filled. ${ }^{37}$

Another literary work in the corpus of English early modern texts about drinking, namely Hans Beer-Pot his invisible comedie, of See me, and See me not (I6I8), similarly exploits the drinking reputation of the Germanic nations. ${ }^{38}$ The name 'Hans Beer-Pot' already indicates a German, Dutch, or Flemish link, ${ }^{39}$ and the subtitle on the titlepage indicates that this play was 'Acted in the Low Countries, by an honest 
Company of Health-Drinkers'. The author, Dabridgcourt Belchier, was in Utrecht at the time, and it seems likely that the play was performed for the amusement of the English troops stationed in Utrecht or elsewhere in the Netherlands. ${ }^{40}$ This play has eight Dutch and English characters, and one character named Don Abnidaraes Quixot, a 'tawnie moore' 'borne in Numidia' who says he is 'a Spaniard, Moore, halfe Turke, halfe Christian'. ${ }^{4 \mathrm{I}}$ They all play little scenes alone or in small groups and discuss - in monologue, dialogue or song - the pleasures of drinking, the art of poetry, the merits of infantry and cavalry, the characteristics of a good woman, the decline in respect for soldiers, and the changing face of fortune. It has been suggested in the past that this comedy might be a translation of an unidentified Dutch play, ${ }^{42}$ but this seems unlikely considering the many English references in the text. ${ }^{43}$ The Dutch elements, such as the names of the characters, are in fact superficial and seem only to be inspired by the fact that the play was intended to be performed in the Low Countries. Another element might have been the desire to advertise the Dutch connection and profit from their reputation in drinking matters in order to sell more copies of the printed version produced in London (and thus aimed at an audience different from the original one).

The national stereotype of heavy drinking in the Low Countries explains why the English turned to these countries when addressing the issue of drunkenness. Hence the translation of Dutch texts, such as the Lytyll treatyse . . called The .ix. Drunkardes. The status of the source culture also clarifies why other texts, such as Hans Beer-Pot his invisible comedie, showcase a connection with a Dutch background, which has led scholars to conclude - mistakenly — that we might be dealing with a translation. The desire to exploit the reputation of the Low Countries and the German-speaking territories furthermore explains the existence of the pseudo-translations Wine, Beere, and Ale and Drinke and welcome, in which an English author decided to present his original composition as a translation from Low or High Dutch. In effect, what happens in the case of these pseudo-translations is the exact opposite of what happens in the case of genuine translation: a domestic discourse is foreignized by presenting it as a translation, as opposed to a foreign discourse being domesticated through the act of translating.

But why are these discourses foreignized? And how successful is the 'forgery'? It is clear that no real effort is made to deceive the reader in the case of Wine, Beere, and Ale. The entertainment value prevails and the connection with a Dutch source is most probably claimed to add an extra element of humour, ascribing the discussion of the various alcoholic drinks to a Dutchman, who - according to the stereotype - should be a specialist. No mention is made of the Dutch connection in the text itself, nor in the foreword by John Grove. Moreover, internal elements quickly disprove it: in the very first lines, allusion is made to the sugaring of wine, a habit which was apparently confined to England; and the text refers to New River, an artificial waterway on the outskirts of London, and to acts passed by the English king for repressing drunkenness. ${ }^{44}$ It is thus not surprising that the claim is abandoned in the later editions: neither the 1630 reprint, nor the 1658 one mentions Gallobelgicus or the fact that this is a translation. The omission should perhaps be connected with the addition of a praise of tobacco in the revised version, because there was no stereotypical 
connection between tobacco and the Low Countries and therefore less reason to advertise a link with them.

Somewhat more effort is made in Drinke and welcome in order to maintain the fiction that this is a translation of a German original. The text opens with an address of (the fictional) Huldrick Van Speagle to the reader, in which he apologizes for writing about alcoholic drinks in use on the British Isles:

I, Huldrick Van Speagle, doe ingeniously confesse my boldnesse, and crave pardon of the Brittains and Irish Nation; for that I (being a stranger) have presumed to write of such Drinkes as are Potable in their Climates and Countries; with such particularities of their Originals and vertues, as I have by experience and practise, with my collections out of divers learned Authors gathered. ${ }^{45}$

John Taylor perhaps stressed the fake German origin of the text in these opening lines to add authority to his message: praise of English ale sounds more convincing coming from an outsider ('a stranger' - meaning foreigner — as he is called in the text), who is furthermore - again according to the national stereotype - an expert in drinking. As in the case of Wine, Beere and Ale, though, the attentive reader nonetheless sees through the fiction almost immediately. Further on in the text, the author speaks of the county of Gloucestershire as 'my native Country' (f. $\mathrm{A}_{2}$ ) of the British Isles as 'these parts' (f. $A_{3}{ }^{v}$ ), and of England as 'our Land' (f. A4 $4^{\mathrm{v}}$ ). He furthermore refers to the time that he was imprisoned in the 'Woodstreet Countertrap', the London jail for debtors and drunks, and mentions English legislation concerning sack (both $\mathrm{f} . \mathrm{B}_{4}^{\mathrm{r}}$ ). Finally, the author identifies himself in the closing lines as 'a Water-man' (f. DI ${ }^{v}$ ), confirming the attribution to Taylor, who was a London waterman and called himself 'the Water-Poet'.

It is thus clear that neither of the two texts under discussion was very successful in maintaining the fiction that it was a translation. But then that was undoubtedly not their intention. The advertised connection with a Dutch or German original was intended to position the text more successfully in the market of publications on drinking and to add an element of humour or authority, but not really to 'falsify' the text completely. Besides, regardless of whether they were perceived as translations or not, these texts exploited the reputation of Germany and the Netherlands as heavy-drinking nations; a reputation which informed the views of English readers on drunkenness and provided them with a scapegoat in the event that the drunk Germans and swag-bellied Hollanders were indeed surpassed by the most-potent-in-potting English.

\section{Acknowledgement}

This contribution was prepared in the context of the project Renaissance Cultural Crossroads: An Analytical and Annotated Catalogue of Translations, I473-1640, funded by the Leverhulme Foundation for 2007-20IO and executed at the Centre for the Study of the Renaissance in the University of Warwick. I wish to thank Bernard Capp and Brenda Hosington whose valuable remarks helped shape the final version of this article. 


\section{Notes}

I Wine, Beere, and Ale, Together by the Eares: A Dialogue, Written first in Dutch by Gallobelgicus, and faithfully translated out of the originall Copie, by Mercurius Britannicus, for the benefite of his Nation (London: A[ugustine] M[athewes] for John Grove, I629).

2 All quotes are taken from the critical edition by James Holly Hanford, 'Wine, Beere, Ale, and Tobacco: A Seventeenth Century Interlude', Studies in Philology, I2-I (I9I5), I-54.

3 Wine, Beere, Ale, and Tobacco. Contending for Superiority: A Dialogue. The second Edition, much enlarged (London: T. C[otes] for John Grove, I630). This revised edition was reprinted in the nineteenth century in J. O. Halliwell's Literature of the Sixteenth and Seventeenth Centuries (London: n. pub., I85I).

4 Wine, Beer, Ale, and Tobacco, Contending for superiority: A Dialogue (London: J[ane] B[ell] for John Grove, I658).

5 Drinke and welcome: or the famous historie of the most part of Drinks, in use now in the Kingdomes of Great Brittaine and Ireland; with an especiall declaration of the potency, vertue, and operation of our English Ale. With a description of all sorts of Waters, from the Ocean sea, to the teares of a Woman [...] Compiled first in the high Dutch tongue, by the painefull and industrious Huldricke Van Speagle, a Grammaticall Brewer of Lubeck, and now most Learnedly enlarged, amplified, and Translated into English Prose and Verse. By Iohn Taylor (London: Anne Griffin, I637). Reprinted in Works of John Taylor The Water Poet not Included in the Folio Volume of I630. Second Collection, The Spenser Society I4 (New York: Burt Franklin, I967; facsimile reprint of the edition of I873).

6 Hanford, 'Wine, Beere, Ale, and Tobacco', pp. 6-8 and pp. $\mathrm{I}_{3}-2 \mathrm{O}$.

7 Hanford, 'Wine, Beere, Ale, and Tobacco', p. 6, referring to the Mercurius Britannicus (the first English newspaper) and the Mercurius Gallobelgicus (a Latin periodical printed in Cologne).

8 See the entry about this book in the English Short Title Catalogue (ESTC) <http://etsc.bl.uk/>. The attribution to Taylor seems to be undisputed amongst present-day scholars, no doubt because of internal elements, such as references to England and the author, which I will discuss at the end of this essay.

9 Bernard Capp, 'Taylor, John (I578-1653)', Oxford Dictionary of National Biography (Oxford University Press, 2004 <http://www.oxforddnb. com/view/article/27044>, accessed 20 January 2009) and Bernard Capp, The World of John Taylor the Water-Poet 1578-I653 (Oxford: Clarendon Press, I994), esp. pp. 4, 34, and I54-55.
Io See amongst others A. Lynn Martin, Alcohol, Sex, and Gender in Late Medieval and Early Modern Europe, Early Modern History: Society and Culture (Basingstoke: Palgrave, 200I), pp. I-5 and Adam Smyth (ed.), A Pleasing Sinne. Drink and Conviviality in Seventeenth-Century England, Studies in Renaissance Literature. Volume I4 (Cambridge: D. S. Brewer, 2004).

II This does not exclude the attack against drunkenness as a manifestation of gluttony during the Middle Ages. See G. R. Owst, Literature and Pulpit in Medieval England. A Neglected Chapter in the History of English Letters and of the English People ( $2^{\text {nd }}$ ed., Oxford: Basil Blackwell, I96I) and John M. Bowers, "Dronkenesse is Ful of Stryvyng": Alcoholism and Ritual Violence in Chaucer's Pardoner's Tale', ELH: English Literary History, 57-4 (I990), 757-84.

${ }^{\mathrm{I} 2}$ George Gascoigne, A delicate Diet, for daintiemouthde Droonkardes. Wherein the fowle abuse of common Carowsing, and quassing with hartie draughtes, is honestlie admonished (London: Richard Jones, I 576), f. $\mathrm{A}_{3}{ }^{\mathrm{r}}$ and $\mathrm{A}_{4}{ }^{\mathrm{v}}$. It is worthy of note that this work contains a translation (f. $\mathrm{A}^{\mathrm{v}}-$ $\mathrm{B}_{4}{ }^{\mathrm{v}}$ ) of the sermon 'Admonitio ut ebrietatis malum totis viribus caveatur', erroneously attributed by Gascoigne, and others, to St Augustine. For a discussion of this source text, see C. T. Prouty, George Gascoigne. Elizabethan Courtier, Soldier, and Poet (New York: Columbia University Press, I942), pp. 274-75. The same identification of drunkenness as a 'beastlie vice [...] frequented in England' is found in Philip Stubbes' The Anatomie of Abuses (first published in I583). Cf. the edition by Margaret Jane Kidnie in the series Medieval and Renaissance Texts and Studies, Volume 245 (Tempe, Arizona: Arizona Center for Medieval and Renaissance Studies - Renaissance English Text Society, 2002), p. 158.

${ }^{13}$ Thomas Thompson, A diet for a drunkard: Deliuered in two Sermons at Saint Nicholas Church in Bristoll, Anno Domini. I608 (London: [William Stansby] for Richard Bankworth, I6I2), f. $\mathrm{A}_{4}^{\mathrm{v}}$.

${ }^{14}$ I have consulted the I630 edition: Robert Harris, The drunkards cup (London: the assignes of Thomas Man, I630), f. A2 ${ }^{\mathrm{v}}$.

I5 A number of these texts are discussed in Sandra Clark, The Elizabethan Pamphleteers. Popular Moralistic Pamphlets I580-I640 (London: The Athlone Press, I983), esp. pp. 198-202.

${ }^{16}$ A Contention betweene three bretheren, that is to say, the Whooremonger, the Dronkard, and the Dice-player ... Compiled by Thomas Salter (London: [Thomas East] for Thomas Gosson, I 580 ). The probability of a French intermediary is suggested by Caroline M. K. Bowden, 'Salter, Thomas 
(fl. I579-158I)', Oxford Dictionary of National Biography (Oxford University Press, 2004, <http:// www.oxforddnb.com/view/article/24574>, accessed 5 March 2009).

${ }^{17}$ This translation, entitled 'A treatise of temperance and sobrietie', is published as part of Hygiasticon: $\mathrm{O} r$, The right course of preserving life and health unto extream old age: together with soundnesse and integritie of the senses, judgement, and memorie. Written in Latine by Leonard Lessius, and now done into English (Cambridge: Roger Daniel, I634). Lessius added a Latin translation of the Discorsi to his own treatise, after which the whole Latin work was translated into English.

${ }^{18}$ Here begynneth a lytyll new treatyse or mater intytuled of called The ix. Drunkardes whyche tratythe of dyuerse and goodly storyes ryght plesaunte and frutefull for all parsones for to pastyme with (London: Richard Banckys, 1523), f. $\mathrm{E}_{4}{ }^{\mathrm{r}}$.

19 Piet Franssen, 'Dat Bedroch der Vrouwen. Een onderzoek naar de functie van een $16^{\mathrm{e}}$ eeuwse verhalenbundel', Spektator. Tijdschrift voor Neerlandistiek, I2-4 (I982-83), 270-289 (pp. 27I-72); P. J. A. Franssen, 'Jan van Doesborch (?-I536), printer of English texts', Quaerendo, XVI-4 (I986), 259-80 (p. 273).

${ }^{20}$ Clark, The Elizabethan Pamphleteers, p. I98, also indicates that drunkenness is particularly associated with the Dutch and German nations in the pamphlet literature from I 580 until I640.

${ }^{21}$ K. H. D. Haley, The British and the Dutch. Political and Cultural Relations through the Ages (London: George Philip, I988), pp. I5-I6 and Marijke Meijer Dress, Andere landen, andere mensen. De beeldvorming van Holland versus Spanje en Engeland omstreeks 1659, Nederlandse cultuur in Europese context, monografieën en studies 6 (Den Haag: SDU Uitgevers, 1997), p. II6. See for the similar grouping of Germans, Flemings and Dutchmen amongst the Italians: John Hale, The Civilization of Europe in the Renaissance (London: Fontanapress, $2^{\text {nd }}$ ed., I994), p. 62.

${ }^{22}$ Gascoigne, A delicate Diet, for daintiemouthde Droonkardes, f. $\mathrm{C}_{2}{ }^{\mathrm{r}}$.

${ }^{23}$ Gascoigne, A delicate Diet, for daintiemouthde Droonkardes, f. $\mathrm{C}_{4}{ }^{\mathrm{r}}$.

${ }^{24}$ Thomas Nash, Pierce Penilesse his Supplication to the Diuell. Describing the ouer-spreading of Vice, and suppression of Vertue (London: Richard Ihones, I 592), f. $22^{\mathrm{v}}-23^{\mathrm{v}}$.

${ }^{25}$ Henry Peacham, The compleat gentleman fashioning him absolute in the most necessary o commendable qualities concerning minde or bodie that may be required in a noble gentleman ([London]: [John Legat] for Francis Constable, I622), p. I94: 'Within these fiftie or threescore yeares it was a rare thing with vs in England, to see a Drunken man, our
Nation carrying the name of the most sober and temperate of any other in the world. But since we had to doe in the quarell of the Netherlands, about the time of Sir John Norrice his first being there, the custome of drinking and pledging healthes was brought ouer into England'.

${ }^{26}$ Matthew Scrivener, A treatise against drunkennesse: described in its nature, kindes effects and causes, especially that of drinking of healths. To which are added, two short sermons of $S$. Augustine's, De tempore (London: for Charles Brown, I685), p. II4: 'When Queen Elizabeth gave assistance to the distressed Netherlands, these Succours soon learn'd the Art, and catched the Disease of Drinking, rife in those Countries, and transported the same soon after into England'.

${ }^{27}$ F. K. Stanzel, 'National Character as Literary Stereotype. An Analysis of the Image of the German in English Literature before I800', London German Studies, I (I980), IOI-I5.

${ }^{28}$ Quoted from the English translation The manners, lawes, and customes of all nations. Collected out of the best Writers by Ioannes Boemus Aubanus, a Dutch-man ... Written in Latin, and no newly translated into English. By Ed. Aston (London: G. Eld, I6II), p. 252.

29 Ioannis Barclaii Icon animorum (Londini: Ex officina Nortoniana apud Iohannem Billium, I6I4), p. 99: 'Immensa cupiditas potus, iam confesso vitio, ideoque magis libero, illam gentem infestat'. English translation quoted from The Mirrour of Mindes, or, Barclay's Icon animorum, Englished by T. M. (London: John Norton for Thomas Walkley, I63I), p. I48.

${ }^{30}$ Ioannis Barclaii Icon animorum, pp. II8-I9; The mirrour of mindes, p. 178 .

${ }^{3}$ See, e. g. William Temple, Observations upon the United Provinces of the Netherlands, ed. George Clarke (Oxford: Clarendon Press, I972), p. 90. For the Spanish chroniclers, and especially Alonso Vázquez, see Yolanda Rodríguez Perez, De Tachtigjarige Oorlog in Spaanse ogen. De Nederlanden in Spaanse historische en literaire teksten (circa 1548-I673) (Nijmegen: Vantilt, $3^{\text {rd }}$ ed., 2005), pp. I69-I72 and J. C. M. Boeijen, 'Een bijzondere vijand. Spaanse kroniekschrijvers van de Tachtigjarige Oorlog over de Nederlandse volksaard', in: P. J. A. N. Rietbergen - F. M. A. Robben H. de Schepper (eds.), Tussen Twee Culturen. De Nederlanden en de Iberische Wereld I550-I800, Nijmeegse Publikaties over de Nieuwe Geschiedenis 2 (Nijmegen: Instituut voor Nieuwe Geschiedenis der Katholieke Universiteit te Nijmegen, $2^{\text {nd }}$ ed., I99I), pp. I-II (p. 9).

32 Paralipomena Vergilii \& De rebus inferorum (I545), ms. at Louvain University Library, 32 (olim A 38 ). This manuscript was edited by Henry De Vocht as an appendix to his History of the Foundation and the Rise of the Collegium Trilingue Lovaniense, 
I5I7-I550, vol. IV, Recueil de Travaux d'Histoire et de Philologie 4-Io (Louvain: Bibliothèque de l'Université, 1955). See also Dirk Sacré, 'Nannius's Somnia', in Rudolf De Smet (ed.), La satire humaniste. Actes du colloque international des $3 I$ mars, ter et 2 avril 1993 (Louvain: Peeters, 1994), pp. 77-93.

33 Roger Ascham to Edward Raven, d. d. 20/0I/I55I, i. e. Aschams's Letters, nr. II6, published in The whole works of Roger Ascham, now first collected and revised with a life of the author; by the Rev. Dr Giles, Vol. I, Part II (London: John Russell Smith, I865), pp. 243-27I (p. 248).

34 Anthony Grafton, Joseph Scaliger: A Study in the History of Classical Scholarship. II: Historical Chronology (Oxford: Clarendon Press, I993), p. 375 .

35 Dorothy Macbride Norris, 'Chaucer's Pardoner's Tale and Flanders', PMLA, 48-3 (I933), pp. 636-4I (p. 636). For the connection between Chaucer and Flanders, see also David Wallace, 'In Flaundres', Studies in the Age of Chancer, I9 (1997), pp. 639I.

${ }^{36} \mathrm{~J}$. Huizinga, 'Engelschen en Nederlanders in Shakespeare's tijd', in J. Huizinga, Verzamelde Werken II: Nederland, Haarlem: H. D. Tjeenk Willink \& Zoon, I948), pp. 350-8I; Ton Hoenselaars, Images of Englishmen and Foreigners in the Drama of Shakespeare and His Contemporaries: A Study of Stage Characters and National Characters in English Renaissance Drama Rutherford, NJ: Fairleigh Dickinson University Press, I992) passim; and Ton Hoenselaars, 'Erotische topografie en nationale beeldvorming in de vroegmoderne Engelse letterkunde', in "Typisch Nederlands": De Nederlandse identiteit in de letterkunde, pp. 55-72, pp. 56-6o.

37 Shakespeare, Othello, 2.3, 7I-79, quoted from The Arden Shakespeare Complete Works, ed. by Richard Proudfoot, Ann Thompson and David
Scott Kastan (London: Thomson Learning, revised ed., 200I), p. 954. The connection between drunkenness and Denmark also appears in Hamlet, I.4, I9-24. The reputation of the Flemings is exemplified in The Merry Wives of Windsor, where John Falstaff is characterized as a 'Flemish drunkard' (2.I, I9).

${ }^{8}$ Dabridgcourt Belchier, Hans Beer-Pot his invisible comedie, of See me, and See me not. Acted in the Low Countries, by an honest Company of HealthDrinkers (London: Bernard Alsop, I6I8). A short discussion of this play by Huizinga is found in his 'Engelschen en Nederlanders in Shakespeare's tijd', pp. 367-370.

39 The character Hance Berepot, an obnoxious Fleming with a predilection for alcohol, appeared (probably) for the first time in the anonymous An Enterlude of Welth and Helth (c. I 557). Cf. Hoenselaars, Images of Englishmen and Foreigners, p. 40.

$4^{\circ}$ Matthew Steggle, 'Belchier, Dabridgcourt (bap. I58I, d. I62I)', Oxford Dictionary of National Biography (Oxford University Press, 2004 <http:// www.oxforddnb.com/view/article/ $\mathrm{I}_{98} 8_{3}>$, accessed 5 February 2009).

${ }^{4 \mathrm{I}}$ Hans Beer-Pot his inuisible comedie, $\mathrm{f} . \mathrm{D} 4^{\mathrm{r}-\mathrm{v}}$.

${ }^{42}$ George Ellis, Specimens of the Early English Poets, to which is prefixed, an Historical Sketch of the Rise and Progress of the English Poetry and Language; in Three Volumes, III (London: Henry Washbourne, I 845 ), p. 40.

${ }^{43}$ For example references to 'Englands court', 'Essex, Norreis, Sidney', 'Englands Kingdome' on f. $\mathrm{B}_{4}{ }^{\mathrm{r}}$; 'the canne of English Beere' on f. $\mathrm{CI}^{\mathrm{r}}$; 'English shilling' on f. $\mathrm{D}_{3}{ }^{\mathrm{r}}$; 'London Water-bearers', on f. $\mathrm{F}_{4}{ }^{\mathrm{v}}$, 'English miles' on $\mathrm{f} . \mathrm{GI}^{\mathrm{r}}$; ; and the enumeration of English heroes on $\mathrm{f}$. $\mathrm{G}_{4}{ }^{\mathrm{r}-\mathrm{v}}$. See also Matthew Steggle, 'Belchier, Dabridgcourt'.

${ }^{44}$ See the textual notes in Hanford, 'Wine, Beere, Ale, and Tobacco', p. 44 and 50.

${ }^{45}$ Drinke and welcome, f. $\mathrm{A}_{2}{ }^{\mathrm{r}}$.

\section{Notes on contributor}

Demmy Verbeke received his PhD in Classics from the Katholieke Universiteit Leuven in 2005. He was a research fellow in the Department of History of Harvard University and within the Centre for the Study of the Renaissance at the University of Warwick. He is currently active as post-doctoral fellow of the De Wulf-Mansion Centre for Ancient, Medieval and Renaissance Philosophy at the KU Leuven, where he continues his study of intellectual history (especially transalpine humanism) and the classical tradition.

Correspondence to: Demmy Verbeke, De Wulf-Mansion Centre for Ancient, Medieval and Renaissance Philosophy, Katholieke Universiteit Leuven, Kardinaal Mercier-plein 2, B-3000 Leuven, Belgium. Email: demmy.verbeke@hiw.kuleuven.be. 